\title{
A novel approach for ventilation with Aintree catheter during rigid bronchoscopy: A non-ventilated case report
}

\author{
Rijit bronkoskopide Aintree kateter ile yeni bir ventilasyon yaklaşımı: \\ Ventile edilemeyen olgu sunumuu

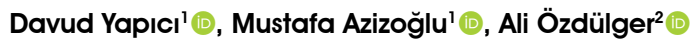 \\ 'Department of Anesthesiology and Reanimation, Mersin University Faculty of Medicine, Mersin, Turkey \\ ${ }^{2}$ Department of Thoracic Surgery, Mersin University Faculty of Medicine, Mersin, Turkey
}

\begin{abstract}
Herein, we present a novel method to overcome difficult ventilation in a patient with a carinal tumor. After induction of anesthesia, we observed difficult ventilation due to obstruction of the right main bronchus as a result of herniation of the tumor mass arising from the left bronchial stump. Traditional lung ventilation techniques were not an option under these conditions. Therefore, the Aintree intubation catheter was used to obtain a patent airway and, with this technique, the patient was successfully and securely ventilated throughout the whole procedure. To the best of our knowledge, this technique is the first to describe successful ventilation during rigid bronchoscopy in a case with a tracheal carinal tumor.
\end{abstract}

Keywords: Catheter ventilation, rigid bronchoscopy, tracheal stenosis.

Airway management during rigid bronchoscopy (RB) for tracheal carinal tumors is one of the greatest challenges for anesthesiologists. ${ }^{[1]}$ Thanks to the recent development of technology observed in the field of surgery and anesthesia, complex trachea and carina tumors can be successfully resected. However, these operations are still difficult to perform. Problems are mainly due to share the same passage with the surgeon and circuit leak due to uncuffed open rigid bronchoscope, resulting in insufficiency to deliver adequate minute ventilation. On the other hand, RB allows endoluminal manipulation of several tools at the same time for its large lumen diameter. In cases with endobronchial masses, biopsies taken with $\mathrm{RB}$ are larger than those obtained with fiberoptic bronchoscope. ${ }^{[2]}$ The Aintree Catheter (Cook Medical Inc., IN, USA) is a semi-rigid tube of $56 \mathrm{~cm}$ length
$\ddot{O} Z$

Bu yazıda karinal tümörü olan bir hastada ventilasyonun zorluklarını aşmak için yeni bir yöntem sunuldu. Anestezi indüksiyonu sonrası, sol bronş güdüğünden köken alan tümör kitlesinin herniasyonu sonucunda sağ ana bronşu tıkamasına bağlı olarak zor ventilasyon gözlendi. Bu koşullar altında geleneksel akciğer ventilasyon teknikleri bir seçenek değildi. Bu nedenle, hava yolu açıklı̆̆ını sağlamak amacıyla Aintree entübasyon kateteri kullanıldı ve bu teknik ile hasta tüm işlem süresince başarılı ve güvenli bir şekilde ventile edildi. Bildiğimiz kadarıyla, bu teknik trakeal karinal tümörlü bir olguda rijit bronkoskopi sırasında başarılı ventilasyonu tanımlayan ilk rapordur.

Anahtar sözcükler: Ventilasyon kateteri, rijit bronkoskopi, trakeal stenoz.

with an internal diameter of $4.7 \mathrm{~mm}$ and an external diameter of $7.0 \mathrm{~mm}^{[3]}$ It was designed to use for assisted fiberoptic intubation and endotracheal tube (ETT) exchange.

Herein, we describe a case in whom an Aintree catheter was successfully used for ventilation and oxygenation during carinal tumor resection with rigid bronchoscope.

\section{SURGICAL TECHNIQUE}

A 68-year-old man with a history of a squamous cell carcinoma of the lung who underwent left pneumonectomy five years ago. He was admitted with preliminary diagnosis of a tracheoesophageal fistula due to recurrent cough. Thoracic computed tomography revealed a tumor at the left main bronchial

Received: February 24, 2020 Accepted: May 11, 2020 Published online: January 13, 2021

Correspondence: Davud Yapıcı, MD. Mersin Üniversitesi Tıp Fakültesi, Anestezi ve Reanimasyon Anabilim Dalı, 33343 Yenişehir, Mersin, Türkiye. Tel: +90 535 - 7246567 e-mail: davudyapici@yahoo.com

Yapıcı D, Azizoğlu M, Özdülger A. A novel approach for ventilation with Aintree catheter during rigid bronchoscopy: A non-ventilated case report. Turk Gogus Kalp Dama 2021:29(1):129-132 


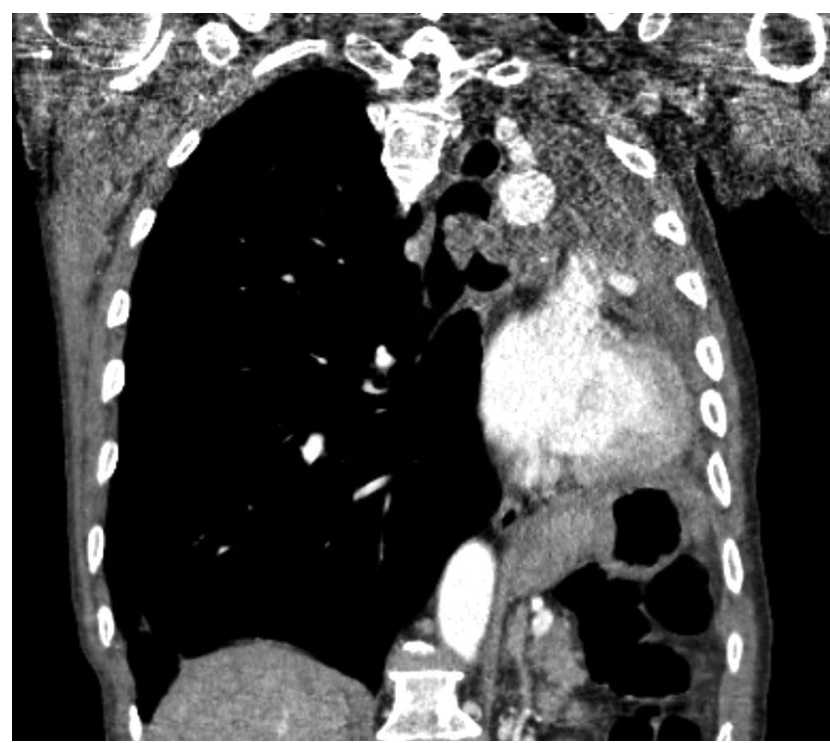

Figure 1. A thoracic computed tomography scan showing a carina-containing tumor in left main bronchial stump.

stump involving the carina. The right main bronchus was open. A written informed consent was obtained from the patient for fiberoptic bronchoscopy (FOB). At the operating room, respiratory and other vital signs were stable. External features did not suggest potentially difficult intubation and a risk of mask ventilation difficulty. After standard non-invasive monitoring, anesthesia was induced with propofol $2 \mathrm{mg} / \mathrm{kg}$, remifentanil $50 \mu \mathrm{g}$, and rocuronium $50 \mathrm{mg}$. Difficult mask ventilation was encountered immediately after the induction of anesthesia, and the patient was rapidly intubated. The FOB was performed due to the continuation of the difficulty in ventilation. During the procedure, a lesion originating from the left main bronchus was observed which caused near total obstruction of the right main bronchus by herniation over carina. After the bronchoscope was introduced distal to the obstruction, the ETT was railroaded over it into the right main bronchus to provide ventilation. Based on these findings, RB was decided upon with the surgical team to reduce the mass for re-establishing ventilation through a potent right main bronchus.

\section{Ventilation technique}

The Aintree catheter was placed through the ETT into the right main bronchus under FOB guidance, and ETT was removed after satisfactory ventilation was achieved (Figure 1). A rigid bronchoscope (Storz, $8.5 \mathrm{Fr}, 45 \mathrm{~cm}$ ) was passed alongside the Aintree catheter into the trachea (Figure 2). The right main bronchus opening was achieved by tumor reduction with biopsy forceps and cauterization through rigid bronchoscope (Figure 3).

No tracheoesophageal fistula was observed. Bronchoscopy was terminated upon restoring airway patency. A size of 8.0 tracheal tube was railroaded over the Aintree catheter. The total procedural time was less than $30 \mathrm{~min}$, and the patient was extubated uneventfully in the operating room. He was transferred from the intensive care unit to the oncology ward after

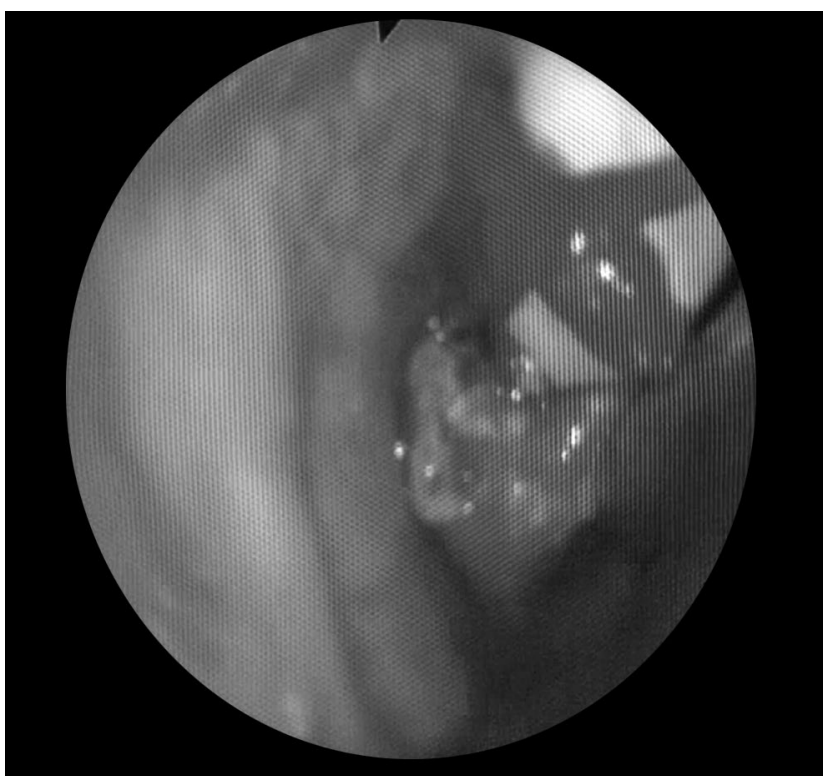

Figure 3. A bronchoscopic endotracheal view after Aintree catheter passing distal to lesion (catheter at 2 o'clock position). 
one day follow-up to continue radiotherapy and he was discharged on postoperative Day 4.

\section{DISCUSSION}

A variety of options are available for ventilation during $\mathrm{RB}^{\left[{ }^{[4]}\right.}$ To achieve adequate oxygenation and ventilation via an uncuffed open rigid bronchoscope requires the use of ventilation strategies established by local expertise, equipment availability, and individual patient-related factors. Regardless of the ventilation technique, close communication between the thoracic surgeon and the anesthesiologist is essential.

Tumor debulking treatment provides immediate relief from airway obstruction ${ }^{[5]}$ and tracheal narrowing requires a smaller size, extra-long, rigid tracheal tube during procedure. ${ }^{[6]}$ The Aintree catheter has a narrower external diameter than a tracheal tube of the same internal diameter. In addition, it is longer than ETT to facilitate procedure during RB. It is a blunt-tipped and semi-rigid plastic sheath with internal and external diameters of $4.7 \mathrm{~mm}$ and $7.0 \mathrm{~mm}$, respectively. It is supplied with a $15-\mathrm{mm}$ connector to allow ventilation and oxygenation. The width and consistency of the catheter resist any tendency to kink during the railroading phase of the intubation.

In our case, the aforementioned features enabled us to pass the rigid bronchoscope alongside the catheter, while providing adequate ventilation with minimal air leak. This combination, also, resulted in safe debulking

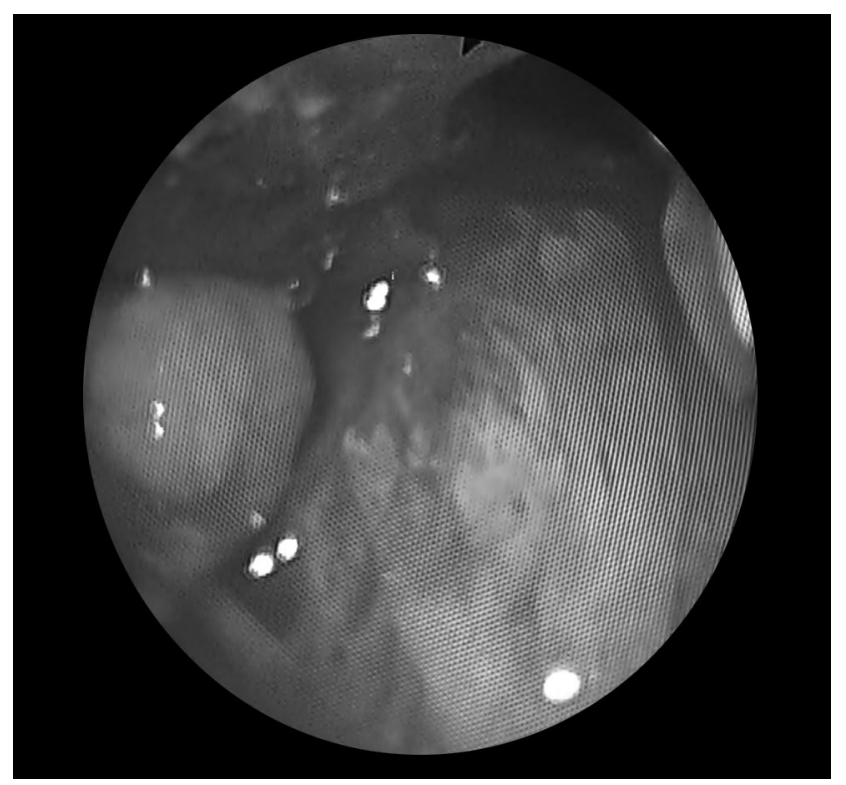

Figure 4. A bronchoscopic endotracheal view of clear right main bronchus after debulking. of the lesion. A similar method consisting of the use of a small-size ETT alongside the rigid bronchoscope through the same passage resulted in some ventilation problems due to kinking and extreme narrowing of the ETT. $^{[4]}$

Currently, two ventilation techniques are widely used in patients undergoing RB ${ }^{[4]}$ In closed system, controlled ventilation technique, rigid bronchoscope is used similarly to an ETT to provide ventilation under positive pressure ventilation. Although no head-to-head studies have been undertaken, manual jet ventilation is the most widely used mode of ventilation in patients undergoing RB today. ${ }^{[7]}$ It uses a high-pressure gas source applied to open airway in short bursts via a small-bore soft catheter. The catheters used for jet ventilation are made of soft silicon which would not be suitable in the presented case to pass beyond the tumor. These two traditional lung ventilation techniques were not an option in our case, as the mass caused near-total obstruction of the right main bronchus by herniating over carina. Therefore, the Aintree catheter was placed into the right main bronchus distally to the lesion which allowed sufficient controlled ventilation during debulking of the tumor Figure 4. If available in our center, jet ventilation could have been used after the insertion of the Aintree catheter for maintenance of ventilation. However, as no jet ventilation system was available, we continued the procedure by using standard anesthesia machine to obtain a high frequency.

In conclusion, this is a novel approach for ventilation with the Aintree catheter during rigid bronchoscopy in a case with a tracheal carinal tumor and it demonstrates not only feasibility, but also safety of ventilation during procedure. To the best of our knowledge, this is the first report to use such a technique for successful ventilation during $\mathrm{RB}$ in a case with a tracheal carinal tumor. We believe that this approach can be also used in other instances for tracheal lesions where rigid bronchoscopy is to be performed.

\section{Declaration of conflicting interests}

The authors declared no conflicts of interest with respect to the authorship and/or publication of this article.

\section{Funding}

The authors received no financial support for the research and/or authorship of this article.

\section{REFERENCES}

1. Dincq AS, Gourdin M, Collard E, Ocak S, D’Odémont JP, Dahlqvist C, et al. Anesthesia for adult rigid bronchoscopy. Acta Anaesthesiol Belg 2014;65:95-103. 
2. Semaan R, Yarmus L. Rigid bronchoscopy and silicone stents in the management of central airway obstruction. J Thorac Dis 2015;7(Suppl 4):S352-S62.

3. Charters P, O'Sullivan E. The 'dedicated airway': a review of the concept and an update of current practice. Anaesthesia 1999;54:778-86.

4. Pathak V, Welsby I, Mahmood K, Wahidi M, MacIntyre N, Shofer S. Ventilation and anesthetic approaches for rigid bronchoscopy. Ann Am Thorac Soc 2014;11:628-34.

5. Hardavella G, George J. Interventional bronchoscopy in the management of thoracic malignancy. Breathe (Sheff) 2015;11:202-12.

6. Young-Beyer P, Wilson RS. Anesthetic management for tracheal resection and reconstruction. J Cardiothorac Anesth 1988;2:821-35.

7. Yarmus L, Feller-Copman D. New bronchoscopic instrumentation: a review and update in rigid bronchoscopy. In: Beamis JF, Mathur PN, Mehta AC, editors. Interventional pulmonary medicine. 2nd ed. New York: Informa Healtcare; 2010. p. 1-9. 